\title{
Assessment of genetic diversity of finger millet blast isolates in Tamil Nadu
}

\author{
C. ANJU* AND R. RABINDRAN
}

Department of Plant Pathology, Tamil Nadu Agricultural University, COIMBATORE (T.N.) INDIA

\section{ARITCLE INFO}

Received : 10.02 .2016

Accepted : 24.03.2016

\section{KEY WORDS :}

RAPD, Finger millet, Blast, Magnaporthe grisea

*Corresponding author: Email: anjuantoney@gmail.com

\begin{abstract}
Blast disease caused by Magnaporthe grisea is one of the major production constraints in finger millet. Fourteen $M$. grisea isolates collected from blast infected leaves and panicle from different locations of Tamil Nadu were subjected to randomly amplified polymorphic DNA (RAPD) analysis using 16 different random primers for assessing diversity. A total of 83 DNA fragments in the range of 200 to $2000 \mathrm{bp}$ were amplified of which, 62 bands $(74.7 \%)$ were polymorphic. Cluster analysis with unweighted pair group method of arithmetic averages (UPGMA) identified two main clusters.
\end{abstract}

How to view point the article : Anju, C. and Rabindran, R. (2016). Assessment of genetic diversity of finger millet blast isolates in Tamil Nadu. Internat. J. Plant Protec., 9(1) : 322-328. 